\title{
Semantic Mutuality in Concepts and Reflection of National Cultural Specificity in Their Transformation Based on Chingiz Aitmatov's Works
}

\author{
Gulmira Turgunova1, Gulsaira Ibraimova ${ }^{2}$, Nurbek Shabdanaliev ${ }^{1}$, Zina Karaeva ${ }^{3}$, \\ Marina Pimenova4, Zhypargul Abdullaeva ${ }^{5 *}$
}

\author{
${ }^{1}$ Department of Linguistics, Academic Consortium International University of Kyrgyzstan, Bishkek, Kyrgyzstan \\ ${ }^{2}$ Department of Science, Ministry of Education and Science of the Kyrgyz Republic, Bishkek, Kyrgyzstan \\ ${ }^{3}$ Department of Philology, Academic Consortium International University of Kyrgyzstan, Bishkek, Kyrgyzstan \\ ${ }^{4}$ Institute of Foreign Languages, St. Petersburg, Russia \\ ${ }^{5}$ Science and Research Department, Osh State University, Osh, Kyrgyzstan \\ Email: *jypar.science@oshsu.kg
}

How to cite this paper: Turgunova, G., Ibraimova, G., Shabdanaliev, N., Karaeva, Z., Pimenova, M., \& Abdullaeva, Z. (2021). Semantic Mutuality in Concepts and Reflection of National Cultural Specificity in Their Transformation Based on Chingiz Aitmatov's Works. Open Journal of Modern Linguistics, 11, 621-629.

https://doi.org/10.4236/ojml.2021.114047

Received: July 11, 2021

Accepted: August 14, 2021

Published: August 17, 2021

Copyright $\odot 2021$ by author(s) and Scientific Research Publishing Inc. This work is licensed under the Creative Commons Attribution International License (CC BY 4.0).

http://creativecommons.org/licenses/by/4.0/ (c) (i) Open Access

\begin{abstract}
In this article authors are analyzing questions "What is a person? Where and how was man created? How can a human become a real person?" Questions like these cannot be left unanswered by all humanity. Such philosophical ideas have been relevant since ancient times and are still relevant today. It is impossible to imagine the universe without humankind, nor can a human ask for life without the universe and the environment around it. These two concepts are inseparably linked together, as for the concept of "human", it is known all over the world, because the mythological statement "Adam and Eve" is well known in connection with the emergence of humanity on earth. The social significance and importance in this study based on the topic relevance concepts "man" and "the universe", and their relationship, which are the main components of life on the earth. Moreover, today modern challenges pose big problems for society in the world, and the main task is to remain as human and preserve peace on the earth. The main research purpose is to analyze etymological attributes and structure of the concept "Man"; origin and meanings with characteristics in various characteristics properties belonging to humankind in general.
\end{abstract}

\section{Keywords}

Semantics, Reflection, Concepts, Cultural Specificity, Transformation, 


\section{Introduction}

In Wikipedia the definition for the term Adam is the following: son of the Earth or man; and his wife Eva is living or giving life, in Bible as the first people on Earth, created by God and the ancestor of man. If we turn to the Qur'an to find out the origin of Adam, then the creation of mankind is given as follows: I will make a man out of dry clay (Jusupov \& Ethem, 2017: p. 263).

According to S.G. Vorkachev's theory, it defines the components (attributes and determinants) that make up the symbolic and significant essence of concept (origin and meaning of the concept); the above information determines the etymological attributes and structure of the concept of "Man". A concept itself is a kind of understanding that relates to a generic and specific name; conceptual content includes the entire body of knowledge about the subject or phenomenon: the history of their emergence and change during the entire history of development is determined in the scientific sphere (Golovanova, 2011: pp. 28-29; Demyankov, 2001: p. 45; Levina, 2014: p. 107; Stepanov, 1997). In a narrow sense, the concept is defined as a thought of primarily everyday knowledge; a worldview incorporating the geocentric universe and heliocentric planetary system (Jackendoff, 1989). Currently, there is no clear and precise definition for the term "concept", since it covers several areas: cognitive science, semantics and cultural linguistics (Shulyatikov, 2015).

Let us define the concept "man" and its components. As for the concept of man, he is not considered as a living being with only a head and two legs. The concept of man is very deep and very responsible (Pecknold, 2016). Because the very creation of man is the highest achievement of this cosmic process.

What does the concept of man include? Human beings are capable of thinking, they can do anything, and they live in close contact with the universe (nature). These qualities form the main generalized core of this concept (Kotchoubey, 2018).

But a person has different qualities, and he can be good or bad. However, the concept of "man" is generally perceived as a concept of a person with good human qualities, and its negative qualities are often ignored, because, as we said above, the concept of "man" is at the highest level in the universe. An example of this in Kyrgyz culture is when a person does something bad or when someone else does something that makes them unhappy, such as "Are you human or animal?" The answer to this question alone emphasizes that human beings are superior to animals in their ability to think. Scientists around the world have done and continue to do a lot of research on the human greatness and the universe originality and semantic features characterized in Aitmatov works (Zheenbekova et al., 2020). 
Chingiz Aitmatov was a writer, whose works were revealed in the context of a literary development during the multinational Soviet period (Karabulatova et al., 2015). The famous Kyrgyz writer and philosopher Chingiz Aitmatov addressed the topic of "Man" and "Universe" occupying a central place in almost all of his works. This article emphasized Aitmatov's planetary thinking, his point of view about human life future evolution and destiny in a world scale.

\section{Research Methods}

In this article, etymological analysis, comparative and context analysis methods were used. The etymological analysis is based on the study of words from an etymological point of view, their meaning, the process of analysis, which is used to establish the original form of words, their signs and properties, as well as to determine their initial and subsequent meanings in the process of historical development (Esemuratov, 2017). The comparative method focused on the development of comparative historical linguistics where the concept of "compare" is synonymous with the concept of "collation" (Zurov, 2012). The context analysis method is a text qualitative analysis with purpose of further content interpretation and numerical regularity (Chernobrovkina, 2011).

Characters in the Chingiz Aitmatov works with writer's notes about humankind were analyzed; various meanings of the concept "Adam" with its components, meanings of expressive values according to thinking, character and happiness were shown.

\section{Chingiz Aitmatov Works about Human Concept}

Ch. Aitmatov reveals the noble qualities of a concept man in his works through his characters. The most interesting thing is that Aitmatov's characters are ordinary persons who, through their personal character, thoughts, views, imaginary worldview, attract the attention of all humankind, conscience and dishonesty, power and conscience, happiness and unhappiness, cowardice and bravery, and so on. The overcrowded, intricate, innate forces us to choose what is good and what is bad, forcing us to think about universal human problems.

As the famous thinker $\mathrm{Ch}$. Aitmatov noted: "The hardest thing for a man is to be a man for a day" has become one of the most pressing issues in our time. The question is: why? This is because a person's behavior caused by his attitude towards the world. It is an indisputable fact that man today is working against man, creating troublesome problems and ultimately causing great harm and the current situation is a great fact.

Why did man come into the world, what is his mother's purpose, and how can he be happy? Happiness is one of the most important components of human concentration (Veenhoven, 2008; Buijs et al., 2021). If we remove the component of happiness from man, then man becomes a mere living being without any support and self-confidence. What do you think is the reason for this? There are billions of people on the earth. You might ask, not all of them are happy, yes! 
Millions of people go about their daily lives without even thinking about happiness. Especially in today's fast-paced world of globalization through a process known as homogenization (Herrington, 2013), people are programmed to live and communicate in the environment.

In many works by Ch. Aitmatov, there is a theme of faith in human, the theme of the ideal, he is looking for a person who can change reality; only one who is true to his ideals will be strong in life (Arstanbekova, 2014). In the concept sphere of Ch. Aitmatov, worldview spheres in human life are associated with good, spiritual and basic concepts that form moral aspect in person life (Chonmurunova, 2016).

\section{Various Meanings of Concept "Adam"}

Of course, it can be said on the contrary, that people have a great opportunity to communicate with people from all over the world. It is true, but in the sphere, we are talking about, man has become by himself. We live in a time when people are only interested in their interests in any relationship. Negotiations and exchanges have to some extent only protected interests. Time has shown us that such relations have no future. Pursues only the personal benefits of man, which will satisfy human needs.

When God created Adam, he endowed him with the highest qualities of humankind, where there is love, trust, compassion for all humanity, generosity, faith, and kindness. In this regard, we will consider the components that make up the concept of "Man" as shown in Figure 1.

If we consider the distinctive features of the concept "man", then we know that man falls into general two categories. They are good and bad categories or qualities in human behavior. In addition, the concept of "human" is divided into so-called categories of many cognitemas (Figures 2-5). These include man's place in society, his place in the family, his relationship with people (Dzyuba, 2011; Karasik, 2000), and his view of the universe and nature. The purpose of our article is to show the happiness of human beings and their close connection with the universe, the highest critical category that forms the core of the human concept.

\section{Concept Universe}

The Universe is known to be closely related to the concepts of "man" and "universe".

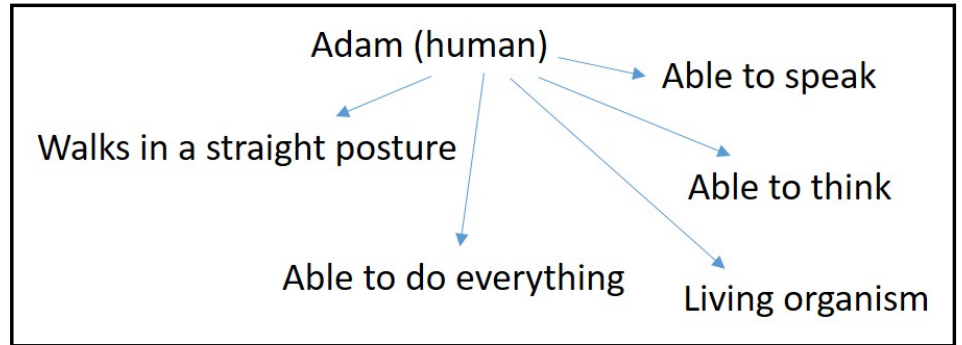

Figure 1. Straight meanings of concept "Adam" with its components. 


\begin{tabular}{|l|}
\hline \multicolumn{1}{|c|}{ Adam (color and appearance) } \\
\begin{tabular}{ll} 
Good: & \multicolumn{1}{c|}{ Bad: } \\
beautiful, pretty, & not beautiful, \\
tall, strong & cold, short stature, \\
\end{tabular} \\
\hline
\end{tabular}

Figure 2. The meanings of expressive values of concept "Adam".

\begin{tabular}{|c|c|}
\hline \multicolumn{2}{|c|}{ Adam (thinking) } \\
\hline $\begin{array}{l}\quad \text { Clever: } \\
\text { educated, sensitive, } \\
\text { understanding, kind, } \\
\text { knows how to love and } \\
\text { can love }\end{array}$ & $\begin{array}{l}\quad \text { Foolish: } \\
\text { uneducated, } \\
\text { incomprehensible, } \\
\text { insensitive, cruel, } \\
\text { incapable of love }\end{array}$ \\
\hline
\end{tabular}

Figure 3. The meanings of expressive values according to thinking.

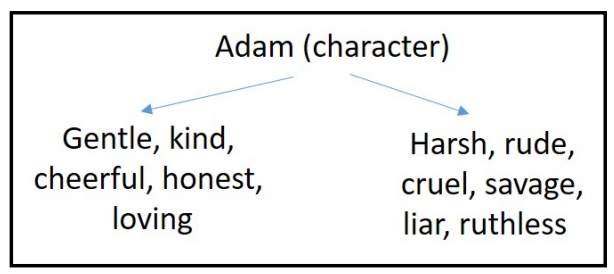

Figure 4. The meanings of expressive values according to a character.

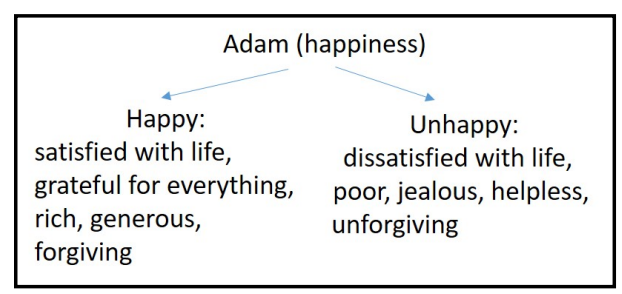

Figure 5. The meanings of expressive values according to happiness.

According to M.B. Pimenova, the concept of "universe" is the basis of language and the core of worldview. The impossibility of governing the universe has been confirmed by a global pandemic. He once again showed humanity that no country with a rich economy and advanced scientific technology can fight this disease. This epidemic spread to all, and it became clear that humanity was weak under it. It was a matter of the universe that ruled us. He proved once again that he is alone and infinite. We have come to understand that humanity is an indivisible part of the universe and that humanity must obey the universe.

The great writer and philosopher Chingiz Aitmatov paid special attention to the problems of man and the universe. In all his works, these two concepts com- 
plement each other. It is no coincidence that the author says, "The hardest thing for a man is to be a man." If we look at the concept of Adam as used here, then the concept of Adam includes both salty and indirect meanings and even higher means that Adam is the highest integral part of the universe. Man has always reminded us to obey the universe and live by its laws, for example, an image of Bazarbai in Aitmatov's novel "Tears of Akbara." Bazarbai, whose name is Adam, got drunk and stole 4 wolves. In doing so, he did not think that even these tiny creatures were living things and that they had a father and a mother. He even yells and beats back at Boston when he asks for bolts. What do you think is the reason for this? This is due to the lack of the criterion of happiness, which is the main core of the concept of man we studied. Bazarbai is unhappy man, a happy hard working person who envies Boston and even envies his wife. The difference between a human being and an animal is that it is humane, able to think deeply, and has a healthy attitude towards the environment. Bazarbay is far from her qualities, and although he is a wolf, he does not know and does not feel that he has motherly love, and that he, like human beings, has infinite love for his children. He cannot distinguish between good and evil. As a result, ten characters in the novel sit in Boston with their own hands. Unable to bear such a tragedy, Boston angrily shot Bazarbay, the cause of all the atrocities.

One type of inverse quality of the concept of "human" that we are studying here (according to Figure 5) proves that human unhappiness is the core of this cognition. This is the only proof that all human activities are based on this most basic concept of happiness.

M.E. Darbanov, in his monograph on the cognitive-linguistic content of the concept of "man", says that even a good person with a kind and loving upbringing can turn into a cruel and unloving person when he gets angry. As evidence of this, he cites the ancient Kyrgyz proverb: "Being human is gradual, being an animal is a past." (Darbanov, 2016: p. 190)

For example, Boston sat down with Bazarbay, he realized that he had gone beyond human limits, and he read to him and said: "Here comes the end?" he said with big voice. Right from here the truth came to him that scared his heart. It is like all the world have been living in him. Now that world lived in him is over and end of the world is close. It seems that world is human. If to think clearly, the sky and the earth are human, all animals and living things mother, mother is wolf Akbara. There was Ernazar, who was frozen in the glacier of Ala-Mongu, his last puppy was Kenzhesh who passed away in hands, whose blood was immiscible even boiling and Bazarbai, who punished last time, all things he saw and experienced were his own universe, all that was lived in him, fight, became less and more, disappeared and appeared; and now this universe will exist as existed from ancient times, but without him Boston, he is another universe, and his universe, his world are unique, not restored and over with this, not burn in anyone, anywhere (Akmataliev, 2018).

As the above example shows that "Man" is the universe, whatever is in a per- 
son's life is his universe. That is why man must remain a man for the rest of his life as a man, otherwise, he will not be able to respond to the sacred name of Adam. Both the universe and Adam were created by the highest Creator and these two concepts are inextricably linked.

\section{Concept Man}

Man is this infinite universe, and the universe is this Man because man's inner world is an infinite universe in itself, but when that infinite universe ceases, human life and his universe will collapse. The universe, on the other hand, is endless because humans live on it.

The concepts of man and the universe we are talking about the form, the core of the works of the great writer Aitmatov and fully answer the question of how the Son of Man can become a man, how a man can live in harmony with the universe.

Ch. Aitmatov's greatness is that he is a human being, and nature shows a strong connection with each other. Through his works, he has always proved to people that animals have hearts in nature and that their loved ones' feelings of love and protection are not alien to them. Animals in the works of Ch. Aitmatov are: Gulsary, Tashchainar, Akbara, Karanar, Jaabars and others who have a sense of love, friendship and protection of loved ones. In Aitmatov's works, the landscape has an active "character", a living "character" and various "characters", they are: loving, generous, playful, cheerful, beautiful, humble, angry, rude, cruel, sad, badtempered, smart, restrained, tired, etc. (Akmataliev, 2018).

Abdyldajan Akmatov, a researcher of Aitmatov's works said: "Aitmatov's landscapes also reflect the strong spirit of the national color, the uniqueness of the Kyrgyz worldview" (Akmataliev, 2018).

The landscape is the environment that surrounds us humans, nature, including the animal world. The man, nature, and the animal world that we are talking about all come together to form the universe. The concepts of man and the universe form the core of the works of this great writer, and they fully answer the question of how the man generation can become a humanity, and how Adam can live in harmony with the universe.

As a result, not all of Chingiz Aitmatov's characters can fully respond to the saying, "The hardest thing for a man is to be human." This was the main philosophical idea that the great writer proclaimed to all humankind.

"Aitmatov's planetary thinking allows us to talk about the future evolution of human life and destiny in a world scale. Aitmatov observed from a height the cosmic changes in the psychology of hundreds of peoples around the world due to extreme situations. For the author, space is not only the universe but also the wealth of the human spirit. And the spirit is an innate category of mankind.

Chingiz Aitmatov's Universe is an infinite world, infinite in space and time. Aitmatov's cosmos is the height of human intellect (Akmataliev, 2018: p. 387).

Firstly, in Aitmatov's works, the main true human idea is growing, based on 
the improvement of human worldview and attitude to nature. Some clearly show that the problems are getting worse.

The greed of the people of the past and the greed of the people of today's globalized society have changed radically, for money has lost the ability to dig up the mother earth for wealth, and even the cosmos has become reluctant to destroy a handful of human beings for personal gain.

\section{Conclusion}

This is where we feel the power of the universe. An example of this is the current pandemic. We must accept this disease as a prohibition imposed on human beings by the universe. The universe has embarked on a method of self-purification and has taken over the education of humankind. This prohibition was the first big warning. How can the man generation become humankind? How can a person be happy? What does it take to be happy? etc. The universe and humankind are inextricably linked categories, and their Creator is one, God. The hardest thing for a human being is to be a human being. This is the highest duty, and every person has to fulfill it.

The practical significance in this work is an application of obtained research results by linguists in conducting a comparative analysis of concepts in languages of different systems, in literary translation and in teaching students to develop intercultural communication skills.

\section{Conflicts of Interest}

The authors declare no conflicts of interest regarding the publication of this paper.

\section{References}

Akmataliev, A. (2018). Ch. Aitmatov: The Universe and Man. Ch. Aitmatov's 10 Volume Collection, V. 10 (364 p.). Uluu Toolor.

Arstanbekova, Z. A. (2014). The Transition from the Genre of the Story to the Novel in the Work of Ch. Aitmatov (pp. 55-66). Peoples' Friendship University of Russia.

Buijs, V. L., Jeronimus, B. F., Lodder, G. M. A., Steverink, N., \& de Jonge, P. (2021). Social Needs and Happiness: A Life Course Perspective. Journal of Happiness Studies, 22, $1953-$ 1978. https://doi.org/10.1007/s10902-020-00287-9

Chernobrovkina, E. P. (2011). Content Analysis in Linguistic Research (pp. 125-129). Buryat State University.

Chonmurunova, N. Z. (2016). Representation of the Concepts of Good and Evil in the Works of Ch. T. Aitmatov (on the Material of the Novel "Scum"). Privolzhsky Scientific Bulletin, 3, 100-104.

Darbanov, M. E. (2016). Cognitive Linguistics Content of Concept “Adam”(294 p.). Bishkek.

Demyankov, V. Z. (2001). Concept and Concept in Fiction and Scientific Language. Questions of Philology, 1, 35-47.

Dzyuba, E. V. (2011). The Concept of "Mind" in Russian Linguoculture: Monograph (224 
p.). Ural State Pedagogocal University.

Esemuratov, A. E. (2017). On the Question of Etymology and Etymological Analysis. Academy, 3, 51-56.

Golovanova, E. I. (2011). An Introduction to Cognitive Terminology(224 p.). Science.

Herrington, L. (2013). Globalization and Religion in Historical Perspective: A Paradoxical Relationship. Religions, 4, 145-165. https://doi.org/10.3390/rel4010145

Jackendoff, R. (1989). What is a Concept, That a Person May Grasp It? Mind \& Language, 4, 68-102. https://doi.org/10.1111/j.1468-0017.1989.tb00243.x

Jusupov, M., \& Ethem, M. (2017). Holy Quran: Introduction to the Kyrgyz Translation of the Meaning of the English Translation and Research at the Scientific Level. Journal of Tafsir Studies, 1, 132-157.

Karabulatova, I. S., Sayfulina, F. S., Zamalieva, L. F., \& Niyazova, G. M. (2015). Chingiz Aitmatov's Creative Works in the National Literature as a Reflection of a New Ethnic Mythology of the Soviet Period. Mediterranean Journal of Social Sciences, 6, 155. https://doi.org/10.5901/mjss.2015.v6n6s2p155

Karasik, V. I. (2000). On the Types of Discourse. Language Personality: Institutional and Personal Discourse (pp. 5-20). Collection of Scientific Works, Change.

Kotchoubey, B. (2018). Human Consciousness: Where Is It From and What Is It for. Frontiers in psychology, 9, 567. https://doi.org/10.3389/fpsyg.2018.00567

Levina, M. A. (2014). Term, Phenomena and Concept. Privolzhsky Scientific Bulletin, 6, 106108.

Pecknold, C. C. (2016). 'Man Is by Nature a Social and Political Animal': Essential and AntiEssentialist Relational Ontologies Revisited. The Heythrop Journal, 57, 883-899. https://doi.org/10.1111/heyj.12000

Shulyatikov, I. S. (2015). The Term “Concept” in Modern Linguistics. Bulletin of Vyatka State University, 12, 98-102.

Stepanov, Y. S. (1997). From the Theory of Literature to the Structure of the Text (pp. 288306). Anthology, Academia.

Veenhoven, R. (2008). Healthy Happiness: Effects of Happiness on Physical Health and the Consequences for Preventive Health Care. Journal of Happiness Studies, 9, 449-469. https://doi.org/10.1007/s10902-006-9042-1

Zheenbekova, G., Nishanova, G., Isakova, A., Kalygulova, S., Sagyndykova, R., Karaeva, Z., Zholdoshaliuulu, K., Tazhibaeva, A., Alieva, C., Abdullaeva, Z., \& Pimenova, M. (2020) Semantic Features of the Concept "Sky" in Different Cultures. Open Journal of Modern Linguistics, 10, 580-587. https://doi.org/10.4236/ojml.2020.105034

Zurov, A. M. (2012). Comparative Method in the Study and Teaching of Foreign Languages (pp. 369-373). Bulletin of the Nizhny Novgorod University. 